\title{
The antecedents and postcedents of satisfaction in business-to-business relationships in South Africa
}

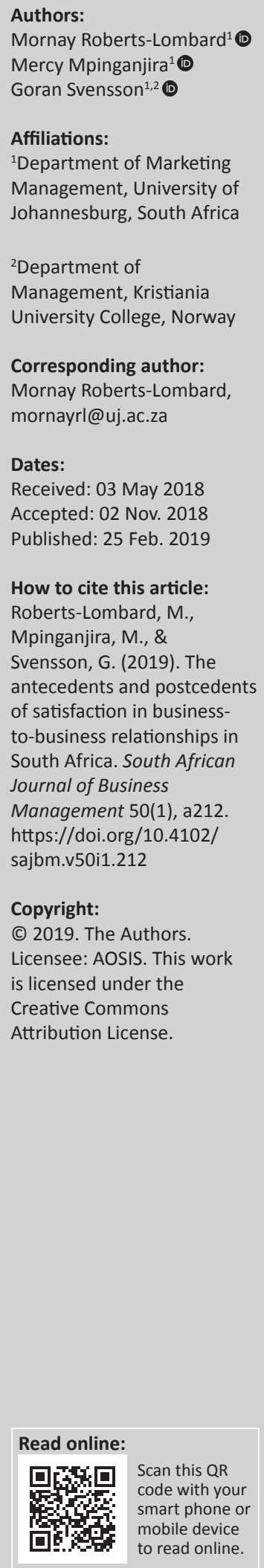

Background: A relationship marketing approach to the management of business relationships can enhance overall customer satisfaction and reduce economic risks, such as opportunism that is associated with business dealings.

Aim: The aim of this study was to establish whether a positive relationship exists between trust and commitment, whether trust has a positive influence on commitment, whether trust and commitment positively influence satisfaction and whether opportunism and conflict are outcomes of satisfaction in South African buyer-supplier relationships.

Setting: Top 500 companies operating in the South African private sector.

Methods: Using a structured questionnaire, data were gathered from 250 large companies in South Africa and were analysed through the application of structural equation modelling (SEM).

Results: The findings indicate that both trust and commitment were perceived as important antecedents of satisfaction in a South African business-to-business environment, and that trust is a precursor to commitment in relationship building between organisational buyers and sellers in South Africa. This study adds value by assisting business-to-business buyers and sellers in South Africa on variables to consider when developing relationship-building strategies.

Conclusion: Both parties to a relationship should therefore build relationships founded on trust and commitment. This will enhance their joint satisfaction, resulting in less opportunism and conflict, and will foster long-term relationship building based on mutual satisfaction. In contrast, dissatisfaction could increase opportunism and conflict between the parties, leading eventually to the termination of their business relationship.

\section{Introduction}

The literature on relationship marketing suggests that trust, commitment and satisfaction are critical to establishing and managing long-term business-to-business relationships (Hess, Story, \& Danes, 2011; Lee, Moon, Kim, \& Yi, 2015; Liao, 2016; Morgan \& Hunt, 1994; Ndubisi, 2007; Wang, Shi, \& Barnes, 2015). Authors disagree on how satisfaction relates to the constructs of trust and commitment. Some research studies perceive commitment, trust and satisfaction as higher order constructs of relationship quality (Chang, Tsai, Chen, Huang, \& Tseng, 2015; Izogo, 2016; Lindgreen, Hingley, Grant, \& Morgan, 2012; Vincent \& Webster, 2013). However, the connection between satisfaction and trust and commitment in the relationship marketing literature is perceived in any of the following ways: as a generator of both trust and commitment (Fullerton, 2011; Han \& Hyun, 2015; Jiménez, San-Martín \& Azuela, 2016; Kaur \& Soch, 2013; Kim, 2014; Su, Swanson, Chinchanachokchai, Hsu, \& Chen, 2016; Valenzuela \& Vasquez-Parraga, 2005), as an outcome of trust and commitment (Candan \& Yildirim, 2008; Dwivedi \& Johnson, 2013; Akman \& Yörür, 2012; Farrelly \& Quester, 2005), as an outcome of trust (Cheng, Chen, Yen, \& Teng, 2017; Jiang, Henneberg, \& Naudé, 2011; Nguyen \& Ngo, 2012; Wu, 2013) and as a mediating variable between trust and commitment and an antecedent to other variables (Ercis, Unal, Candan, \& Yildirim, 2012; Garbarino \& Johnson, 1999; Hutchinson, Singh, Svensson, \& Mysen, 2011).

The central argument through the relationship marketing literature is that trust, commitment and satisfaction are foundations for a long-lasting relationship between two parties (Chen \& Myagmarsuren, 2011; Kruger, Mostert, \& De Beer, 2015; Melewar, Foroudi, Gupta, Kitchen, \& Foroudi, 2017; Sahin, Kitapçi, \& Zehir, 2013; Ndubisi, Malhotra, \& Wah, 2009; Theron, 2012). Numerous researchers also perceive trust and commitment as distinctive variables in the relationship building process (Adamson, Chan, \& Handford, 2003; Chen, Chen, \& Wu, 2017; 
Dagger \& O’Brien, 2010; Sumaedi, Juniarti, Mahatma, \& Bakti, 2015; Zabkar \& Brencic 2004). In addition, some researchers are of the opinion that satisfaction is an important variable in the building of long-term relationships between parties (Akman \& Yörür, 2012; Fatima, Razzaque, \& Di Mascio, 2015; Fernández-Sabiote \& Román, 2016; Sharifi \& Esfidani, 2014). Geyskens, Steenkamp and Kumar (1999) concluded that satisfaction should be perceived as a separate variable to trust and commitment.

In this study, satisfaction is considered an outcome of commitment and trust. This understanding is validated by various researchers:

- Bowden-Everson, Dagger and Elliott (2013, p. 55) state that 'satisfaction is essential to the buyer-seller relationship with trust being reflective of the level of satisfaction in the customer-provider relationship'.

- Fullerton (2011, p. 95) argues that 'consumers tend to identify with and become attached to those organisations that have a track record of delivering satisfactory experiences'.

- Lee et al. (2015, p. 298) refer to satisfaction as an essential component in the building of long-term relationship. Satisfaction is built on trust and commitment and is required to secure a long-term orientation in the relationship between parties.

- Caceres, Nicholas and Paparoidamis (2007, p. 842) argue that satisfaction is a significant component of relationship quality.

Considering the information provided above, it can be argued that satisfaction should be respected as a strong outcome of business relationship which is rarely developed without trust and commitment (Rindell, Mysen, Svensson, \& Billström, 2013, p. 426). The current study includes a focus on variables from both the relationship marketing theory (such as trust, commitment and satisfaction) and the transaction cost theory (such as opportunism and conflict). Furthermore, it posits that the parties to a business-to-business relationship must have a long-term approach towards the relationship (Ng, 2012; Nyaga, Whipple, \& Lynch, 2010; Palmatier, Dant, Grewal, \& Evans, 2006; Payan, Hair, Svensson, Andersson, \& Awuah, 2016; Segarra-Moliner, Moliner-Tena, \& SánchezGarcia, 2013; Voldnes, Grønhaug, \& Nilssen, 2012) through a continuous focus on trust and an understanding that transactional outputs (such as opportunism and conflict) can impact the functioning of business partnerships (Chiou \& Shen, 2006; Kruger et al., 2015; Ozkan-Tektas \& Basgoze, 2017; Ping, 1993; San-Martín \& Jiménez, 2017).

Relationship marketing constructs, such as commitment, satisfaction and trust, have not been tested before in research with the transaction cost theory constructs, such as opportunism and conflict, within an emerging African economy such as South Africa. The aim of this study is therefore to establish whether a positive relationship exists between trust and commitment, whether trust has a positive influence on commitment, whether trust and commitment positively influence satisfaction and whether opportunism and conflict are outcomes of satisfaction in South African buyer-supplier relationships. Most studies on businessto-business relationships are founded on the findings of academic research that was conducted in developed countries, such as the studies by Segarra-Moliner et al. (2013), Vieira, Monteiro and Veiga (2011), Nyaga et al. (2010) and Skarmeas, Katsikeas, Spyropoulou and Salehi-Sangari (2008). However, no previous study has tested the variables in the proposed model in relation to an emerging market such as South Africa.

This study contributes to the relationship marketing body of knowledge because it indicates that the identified relationships between satisfaction and its antecedents (trust and commitment) and outcomes (opportunism and conflict) are also evident in a business-to-business relationship between a buyer and a supplier. The different constructs of the relationship marketing and transaction cost analysis theories, examined in this study, have also not been investigated in conjunction with one another in an emerging African market such as South Africa. In addition, a model is suggested and validated that demonstrates the business-to-business relationships between customer satisfaction, its precursors and outcomes within a South African business-to-business environment. From a managerial perspective, the study contributes by potentially assisting corporate South Africa in comprehending how trust and commitment can nurture customer satisfaction, which can eventually secure lower levels of opportunism and conflict between parties in a business relationship.

The article first provides a discussion of the theories that ground the study, as well as the different constructs of the study. Then the hypotheses for the study are developed and a theoretical model is suggested. This is followed by a perspective on the research methodology, the findings, the theoretical and practical contribution made and the managerial implications of the study.

\section{Theoretical framework and hypotheses proposed}

The conceptual model for the study is presented in Figure 1. The figure illustrates the position of trust and commitment as antecedents to satisfaction and the position of opportunism and conflict as postcedents of satisfaction. The article is based on the work of Mysen, Svensson and Lee (2011) and further proposes that trust is an antecedent of commitment and that opportunism is a precursor of conflict. The following discussion includes a theoretical overview to support the formulated hypotheses.

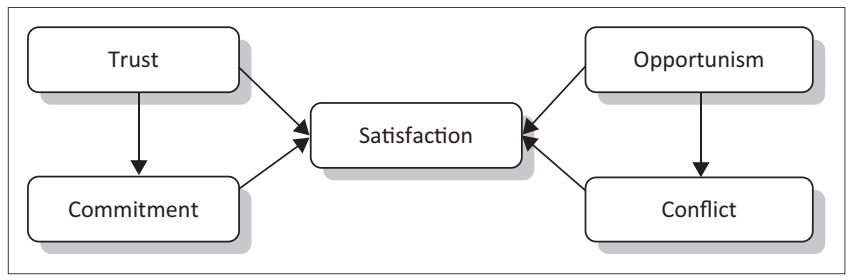

FIGURE 1: Conceptual model. 


\section{Theories grounding the study}

The study is grounded in relationship marketing and transaction cost analysis theories with reference to the variables under investigation and the different relationships proposed between them. The relationship marketing theory originated in the early 1980s, the concept being positioned in the domain of services and business-to-business marketing. This theory was founded on the principle of building longterm profitable relationships with customers, moving away from the transactional approach towards relationship establishment (Gummesson, 2017, p. 17). The commitmenttrust theory of Morgan and Hunt (1994, p. 22) became the foundation of the relationship marketing theory, stating that both trust and commitment are required to secure sustainable long-term relationships. Even today, trust and commitment are being studied as key constructs of the relationship marketing theory, driving customer satisfaction in buyerseller relationships in both business-to-business and businessto-consumer markets (Verma, Sharma, \& Sheth, 2016, pp. 207-208). Gummesson (2002, pp. 50-53) has identified the following five principles that will form the foundation of relationship building in the future: firstly, to value each customer individually; secondly, to secure trustworthy collaboration enabling value creation; thirdly, to understand that it is financially rewarding to invest in long-term relationships; fourthly, to secure win-win relationships for all parties involved; and, finally, to develop relationships based on service values such as ethics, honesty, integrity, reliability and respect for time. Relationships built on such trustworthy principles allow suppliers to become more effective and efficient, resulting in a financial benefit based on customer retention (Samiee, Chabowski, \& Hult, 2015, p. 1). Considering that buyer-supplier relationships are continuously evolving, a deep understanding of the relationship marketing theory is required to secure the establishment and management of customised, long-term relationships. These relationships need to be customised and founded on principles that will secure customer commitment and satisfaction in the long term (Sarmento, Farhangmehr, \& Simões, 2015, p. 586).

The transaction cost theory provides a theoretical foundation for understanding how business-to-business companies function and survive, especially considering that the taking of risks and opportunities is central to conducting business in a business-to-business environment (Sinnewe, Charles, \& Keast, 2016, p. 198). The transaction cost theory originated in fields such as economics, sociology and organisational behaviour. It is significant to the marketing field in describing the advantages of establishing business relationships, with specific reference to corporate sellers and buyers that are engaged in transactions of an 'arm's length' nature (Mpinganjira, Bogaards, Svensson, \& Mysen, 2014, p. 3). The transaction cost theory can be used as a theoretical foundation to understand how trust can be strengthened and opportunism can be reduced in the relationship building process. A positive relationship between trust and satisfaction is also secured through the application of the transaction cost theory in the management of business-to-business transactions
(San-Martín \& Jiménez, 2017, p. 2212). According to Yasuda (2005, p. 763), the transaction cost theory avers that organisational buyers and sellers will commit to a business-tobusiness relationship if overall fixed and continual transaction costs are reduced (inclusive of opportunism and conflict). By including transactional cost in the assessment of business opportunities, a buyer and supplier can establish the risk of fixed and continual transaction costs (such as opportunism and potential conflict) and better understand the requirements for securing a stable relationship (Meghwani \& Thakur, 2017, p. 2). Because of uncertainty in the business-to-business environment, an organisational buyer should increasingly consider the influence of transaction costs when dealing with a supplier, especially when the possibility of opportunism exists, which could reduce overall levels of satisfaction for both parties in the long term (McIvor, 2009, p. 54). Therefore, the transaction cost theory proposes the necessity to safeguard investments that increase transaction costs and thus have a negative influence on the building of long-term relationships between an organisational supplier and buyer (Parida, Wincent, \& Oghazi, 2016, p. 1823). However, safeguarding investment could help to lessen the possibility of conflict between the parties that could arise because of opportunism and/or disagreement, influencing the overall level of satisfaction experienced by both parties (Brown, Lusch, \& Smith, 1991, pp. 15-16; Standifer et al., 2015, pp. 694-695).

Against the background provided above, the study uses the relationship marketing theory and the transaction cost theory to develop hypotheses for relationships between the constructs of the study in a South African business-tobusiness environment. No previous study in a South African business-to-business environment has used relationship marketing theory and transaction cost theory to propose that satisfaction is an outcome of trust and commitment, on the one hand, and an antecedent of continuity and conflict, on the other hand.

\section{The interrelationship between trust and satisfaction}

Trust refers to the preparedness of parties to take on risk and be exposed to another party in the relationship building process (Alhabash et al., 2015, p. 149). It entails the belief by one party that the benefits exceed the risk incurred in establishing and managing a relationship with another party (Sahin, Zehir, \& Kitapç1, 2011, p. 1291). Trust can therefore be seen as a wide-ranging assessment at a more advanced level, compared to satisfaction, with satisfaction being perceived as an outcome of trust. Trust secures the supplier's loyalty to its promised role obligations to secure satisfaction $(\mathrm{Wu}$, Cheng, \& Ai, 2018, p. 202). According to Mpinganjira et al. (2014, p. 5), the principle of trust can be studied from the perspective of interpersonal and inter-firm levels. However, for the purpose of this study, the focus is on investigating trust from an inter-firm perspective. According to various research studies (Amin, Rezaei, \& Abolghasemi, 2014, p. 262; Chen \& Chang, 2013, p. 67; Veloutsou, 2015, p. 407), customer satisfaction is perceived as a critical element in securing a 
long-term relationship orientation. Satisfaction also entails an assessment of economic or psychological factors that can have a positive influence on the building of relationships with customers. Therefore, trust is perceived as an antecedent of satisfaction in business relationships (Altinay, Brookes, Madanoglu, \& Aktas, 2014, 724; Cheng et al., 2017, p. 396; Han \& Hyun, 2015, p. 22; Jiang et al., 2011, p. 6). Considering this, the following hypothesis is proposed:

\section{$\mathbf{H}_{1}$ : Trust positively influences satisfaction.}

\section{The interrelationship between commitment and satisfaction}

Commitment can be described as the confidence of parties to a relationship, illustrating a willingness to preserve the relationship and make short-term sacrifices to secure longterm advantages (Richard \& Zang, 2012, p. 573). Customer commitment encompasses an emotional connection between a buyer and a seller and demonstrates the continuous desire of the buyer to be in a relationship with the seller, or vice versa (Chiu, Kwag, \& Bae, 2015, p. 628; Su et al., 2016, p. 3262). Akman and Yörür (2012, p. 220) concur and state that committed buyers are more willing to support a supplier if the latter secures the provision of high-quality products or services and creates opportunities for continuous engagement, resulting in higher levels of satisfaction. Therefore, a feeling of commitment increases the belief that a supplier will secure results leading to the buyer's satisfaction with the relationship (Fullerton, 2011, p. 95; Payan et al., 2016, p. 66). Considering this, commitment is noted in research literature (Farrelly \& Quester, 2005, p. 212; Kasuma, Ung, Kanyan, Kamri, \& Yacob, 2016, p. 302; Tsao \& Hsieh, 2012, p. 823) as an important antecedent of customer satisfaction and a critical factor in enhancing relationship outcomes such as satisfaction. Therefore, the following hypothesis is formed:

\section{$\mathbf{H}_{2}$ : Commitment positively influences satisfaction.}

\section{Trust as an antecedent to commitment}

The founding theory of Morgan and Hunt (1994, p. 24) on the relationship between trust and commitment established that trust influences relational commitment. The founders of the trust-commitment theory argue that relationships founded on the principle of trust are so greatly appreciated that partners aspire to be committed to such relationships. As commitment requires vulnerability, partners to a relationship will be interested only in a partner that is trustworthy (Chai \& Dibb, 2014, pp. 63-64; Li, Li, \& Feng, 2015, p. 1045; Morgan \& Hunt, 1994, pp. 24-25). Many research studies (Hong \& Cho, 2011; Morgan \& Hunt, 1994; Ou, Shih, \& Chen, 2015, p. 676; Wang, Ngamsiriudom, \& Hsieh, 2015, p. 558) have proven the fundamental relationship between trust and commitment in relational exchange where trust is the focal point of the relationship. Trust is perceived as a critical element in the relationship building process to secure a longterm orientation through the establishment of commitment (Taylor, Donovan, \& Ishida, 2014, p. 129). Ng, Fang and Lien (2016, p. 38) argue that the level of trust existing between a buyer and a seller indicates the possibility of a continuing relationship and its potential for success. They also argue that trust has a positive influence on commitment, because relationships characterised by high levels of trust are strongly valued by relationship partners, resulting in an increased willingness to be committed to the relationship. It can therefore be argued that trust as an antecedent of commitment has been well researched and found to be significant as a predictor of commitment in the relationship building process (Theron, Terblanche, \& Boshoff, 2008, p. 998). Considering this, the following hypothesis is formulated:

$\mathbf{H}_{3}$ : Trust positively influences commitment.

\section{The interrelationship between satisfaction, opportunism and conflict}

The first specified outcome of satisfaction, as per Figure 1, is opportunism. Dahlstrom, Nygaard, Kimasheva and Ulvnes (2014, p. 271) refer to opportunism as the incomplete or distorted disclosure of information, especially to calculated efforts to mislead, distort, or otherwise confuse a trading partner'. It entails behaviour founded on dishonesty and pretence. Therefore, by being aware of opportunism, an organisation can evaluate its standing in relation to that of a business partner and recognise areas where they might become the victim of opportunistic behaviour (Paswan, Hirunyawipada, \& Iyer, 2017, p. 131). Opportunism therefore presents a risk to the building of long-term relationships between an organisational buyer and supplier because it generates insecurity, inadequacies and substantial negative economic effects for exchange relationships (Zhou, Zhang, Zhuang, \& Zhou, 2015, p. 147). Chiou and Shen (2006, p. 11) argue that in a case where the supplier is perceived to pose a high risk of opportunism in a relationship with a buyer, the latter will be required to devote a large number of resources to managing the sources of opportunism. Opportunism can be prevalent in various forms, such as through different types of intentional misrepresentation during the initial stage of the relationship building process between the buyer and supplier, as well as numerous types of infringements over the duration of the relationship (Elsharnouby \& Parson, 2013, p. 146). Opportunism therefore creates a significant challenge to a buyer or a seller wanting to be in charge of or to manage an exchange partner's actions where the propensity for opportunism is high. Ping (1993, p. 326) and San-Martín and Jiménez (2017, p. 2212) note that there is a greater chance of opportunism in relationships where satisfaction between two parties declines, and a lower possibility of opportunism in relationships characterised by high levels of satisfaction and rewarding engagements. The following hypothesis is therefore proposed:

$\mathbf{H}_{4}$ : Satisfaction negatively influences opportunism.

The second outcome of satisfaction, as per Figure 1, is conflict. Conflict refers to incompatible activities by two parties. It arises when there is no or limited delivery on promises made between parties (Mazaheri, Basil, Yanamandram, \& Daroczi, 2011, p. 236). Considering the limited possibility that the objectives of parties to a relationship will be similar, misunderstandings are bound to arise from the different 
goals and unexpected emergencies in their daily relationships, which could result in conflict (Zaheer, McEvily, \& Perrone, 1998, p. 146). Conflict needs to be managed to ensure that it is beneficial to all parties concerned. In addition, conflict should be countered through open dialogue and professional engagement to enhance positive experience and overall satisfaction (Karnani, 2008, pp. 31-32). Ng (2012, p. 166) concurs, stating that increased levels of mutual satisfaction are critical to secure long-term relationships between parties. Varela-Neira, Vázquez-Casielles and Iglesias (2010, p. 104) also state that the professional management of conflict will lead to increased levels of satisfaction. The inability to address conflict may result in higher levels of dissatisfaction or even aggravate emotions of rage and the need to take revenge. Therefore, is the following hypothesis is formulated:

$\mathbf{H}_{5}$ : Satisfaction negatively influences conflict.

\section{Research methodology Research context, population and sample}

The target population of the study included the top South African companies by revenue. The study was quantitative in nature and the sample frame included the largest 500 South African companies. The sample frame was obtained from the Topco list, which comprises the top 500 companies functioning in the South African private sector. The Topco list was selected because this list makes available details of the top 500 companies in South Africa. Companies on the list represent a variety of industries in South Africa, ranging from financial services, agriculture, the mining sector and telecommunications to business support services. The study followed a convenience sampling approach by which the purchasing or procurement managers of the selected companies were contacted by telephone to determine their suitability for answering the questionnaire. Purchasing or procurement managers were selected because the study focused on business relationships with suppliers. Purchasing or procurement managers liaise directly with suppliers in a business, making them more informed about relationship issues with their business suppliers. To gather data from respondents, they were interviewed by means of a structured questionnaire and computer-assisted telephonic interviews. When answering the statements in the questionnaire, the purchasing or procurement managers were requested to focus on a single supplier that they were acquainted with. In total, 250 usable questionnaires were obtained, representing a response rate of $50 \%$.

The questionnaire contained two items to establish the competence of the respondents to answer it. These items established their level of knowledge about their company's view of the study topics and on particular experiences with the supplier. This approach is supported by Campbell (1955), who states that individuals who are selected to complete a questionnaire should be knowledgeable on the topic being investigated. The results illustrate that a total of $94.8 \%$ of those who responded were familiar with the viewpoint of their company in terms of the topic under study. In addition, a total of $98.4 \%$ respondents had comprehensive knowledge about experiences with a specific supplier. The mean values for these two items were 4.26 and 4.33 , respectively. These mean values indicate that the purchasing or procurement managers who responded had a suitable understanding of their company's perspective on the topics being investigated and the experience that their companies had with a supplier. The statement relating to specific experiences with the supplier sought to determine the level of knowledge that the purchasing or procurement managers had gained through specific, and not simply general, experiences with the supplier whom they considered when responding to the different items in the questionnaire.

\section{Measures and scale items}

Table 1 illustrates the different items used to measure the constructs illustrated in Figure 1. The items used to measure the interrelationship between antecedents, mediator and postcedents were adapted from various sources as indicated below:

- Antecedents:

- Trust - items were adapted from Zaheer et al. (1998).

- Commitment - items were adapted from Anderson and Weitz (1992) and Morgan and Hunt (1994).

- Mediator:

- Satisfaction - items were adapted from Andaleeb (1996).

- Postcedents:

- Opportunism - items were adapted from Dahlstrom and Nygaard (1999).

- Conflict - items were adapted from Brown, Lusch and Nicholson (1983), Coughlan, Anderson, Stern and ElAnsary (2001), Lee (2001) and Ren and Gray (2009).

Existing scales were used in the study as Peter (1979) and Churchill (1979) argue that existing scales improve validity.

TABLE 1: Scale items: Original study and replication study.

\begin{tabular}{ll}
\hline Construct & Items \\
\hline Trust & (a) This supplier is fair in its negotiations with us. \\
(b) We can rely on this supplier to keep promises made to us. \\
(c) This supplier is trustworthy. \\
Commitment \\
(a) We would like to continue our work with this supplier. \\
(b) We intend to do business with this supplier well into the future. \\
(c) We are dedicated to continuing doing business with this supplier. \\
Satisfaction \\
(a) Our firm is comfortable about its relationship with this supplier. \\
(b) The relationship between this supplier and us is positive. \\
(c) The relationship between this supplier and us is satisfying. \\
Opportunism & (a) This customer hides important information that is of interest to us. \\
(b) This customer does not always keep what he promises. \\
(c) Sometimes, this customer alters the facts slightly in order to get \\
(d) This customer sometimes promises to do things without actually \\
doing them later. \\
(e) This customer is not always honest with us. \\
(a) We often have disagreements with this customer. \\
(b) We often have different opinions when dealing with this \\
customer. \\
(c) We often have different opinions when negotiating a new \\
contract with this customer. \\
(d) There is much conflict in the relationship with this customer. \\
(e) People often get angry in our firm when dealing with this \\
customer.
\end{tabular}


The study made use of a five-point Likert-type scale to determine the degree to which respondents agreed or disagreed with the items provided in the questionnaire. The scale points ranged from (1) 'strongly disagree' to (5) 'strongly agree' (see Table 1).

\section{Ethical consideration}

Ethical consideration provided for this study: MRL/MM/ GS/001/16.

\section{Results}

\section{Measurement models}

Confirmatory factor analysis (CFA) and structural equation modelling (SEM) were used to test the measurement model and evaluate the proposed structural relationships shown in Figure 1 (Jöreskog \& Sörbom, 1976). The researchers first conducted CFA of the measurement model (19 indicator variables as in Figure 2), founded on five constructs, applying the SPSS/AMOS 22.0 software. The testing of the model produced reliable and acceptable findings. The goodness-of-fit measures were all acceptable (Hair, Black, Babin, Anderson, \& Tatham, 2006, pp. 745-749), as shown in Table 2.

Table 3 illustrates the results for construct reliability and validity testing. The results indicate that the variance extracted from items for all constructs exceeds $50 \%$ in the

TABLE 2: Goodness-of-fit measures of the measurement model in the study.

\begin{tabular}{lllllllll}
\hline CMIN & $d f$ & $p$ & CMIN or $d f$ & NFI & IFI & TLI & CFI & RMSEA
\end{tabular}

\begin{tabular}{lllllllll}
\hline 104.753 & 80 & 0.33 & 1.309 & 0.96 & 0.99 & 0.98 & 0.99 & 0.035
\end{tabular}

$\mathrm{CMIN}$, minimum value of the discrepancy; $d f$, degrees of freedom; $p$, $p$-value; NFI, normed fit index; IFI, incremental fit index; TLI, Tucker-Lewis co-efficient; CFI, comparative fit index; RMSEA, root mean square error of approximation.

TABLE 3: Squared inter-construct correlations and summary statistics.

\begin{tabular}{lccccc}
\hline Variable & Trust & Commitment & Satisfaction & Opportunism Conflict \\
\hline Trust & 1.000 & - & - & - & - \\
Commitment & 0.73 & 1.000 & - & - & - \\
Satisfaction & 0.75 & 0.67 & 1.000 & - & - \\
Opportunism & 0.27 & 0.10 & 0.18 & 1.000 & - \\
Conflict & 0.21 & 0.13 & 0.18 & 0.28 & 1.000 \\
Variance extracted (\%) & 60 & 86 & 75 & 52 & 61 \\
$\begin{array}{l}\text { Composite trait } \\
\text { reliability }\end{array}$ & 0.85 & 0.95 & 0.91 & 0.82 & 0.86 \\
\hline
\end{tabular}

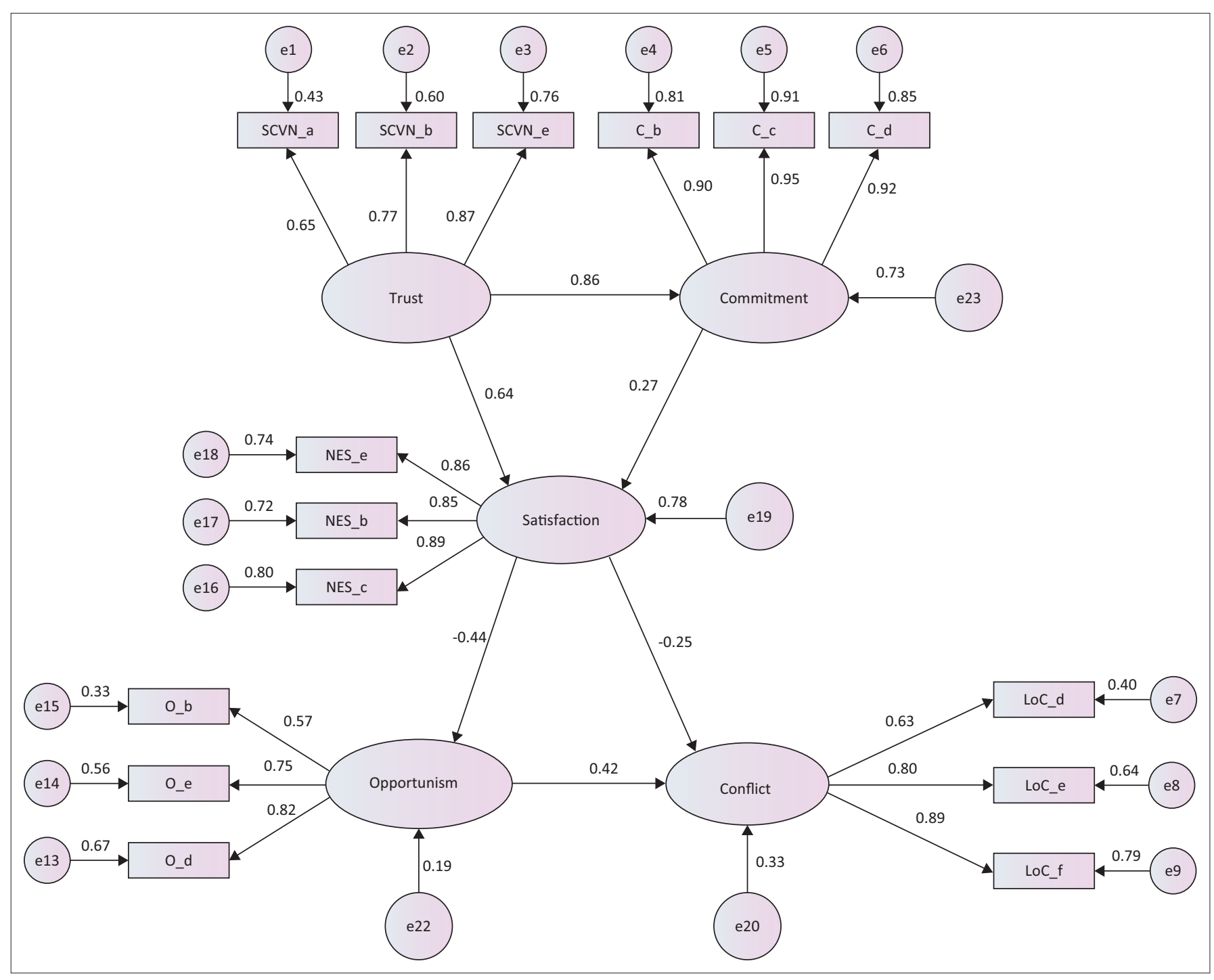

FIGURE 2: Five-construct structural model. 
study, clearly reflecting convergent validity. The average explained variance is $66.9 \%$, and the composite trait reliability levels of all the constructs included in the study are also above 0.7 (Hair et al., 2006).

In addition, the variance extracted was compared with the squared inter-construct correlations to determine whether the model measured different constructs (Hair et al., 2006). In the study, the variance extracted for the majority of the constructs was equal to or greater than the corresponding squared inter-construct correlations (see Table 3). It can therefore be argued that the tested structural model reflects satisfactory discriminant validity in the study (see Figure 2). The hypothesised relationships of the model were all significant in the study, clearly reflecting nomological validity. The testing of the model in the study with specific reference to South African business relationships attained convergent, construct and nomological reliability. It can therefore be argued that the measurement and structural metrics of the model display fully consistent validity and reliability.

\section{Structural model}

Based on the satisfactory results from the CFA of the measurement model, founded on South African business relationships, the researchers tested the structural model, illustrated in Figure 2.

Once the assessment of the psychometric properties of the measurement model was completed and the checking of the underlying assumptions was done, the structural properties of the model had to be secured. Different goodness-of-fit measures were measured in the structural model, as was the case in the measurement model. These measures include the chi-square, the normed chi-square $\left(\chi^{2} / d f\right)$, the NFI, RFI, IFI, TLI, CFI and the RMSEA. The results reflected by Table 4 clearly indicates that the different goodness-of-fit measures are within the parameters as recommended by Hair Black and Babin (2014). The normed chi square $\left(\chi^{2} / d f\right)$ are below the value of 3 , the NFI, RFI, IFI, TLI and CFI are all in excess of the cut-off of 0.9 , and the RMSEA is below a value of 0.08 . The combination of the goodness-of-fit measures as reported in Table 4 is therefore an indication of a good model fit (Hair et al., 2014).

Furthermore, the structural model's hypothesised relationships (see Figure 2) were all significant, as illustrated in Table 5. Accordingly, the results support the six hypotheses of the confirmed model on South African business relationships in the study.

TABLE 4: Goodness-of-fit measures of the structural model.

\begin{tabular}{lllllllll}
\hline CMIN & $d f$ & $p$ & CMIN or $d f$ & NFI & IFI & TLI & CFI & RMSEA \\
\hline
\end{tabular}

\begin{tabular}{lllllllll}
\hline 122.129 & 84 & 0.004 & 1.454 & 0.954 & 0.985 & 0.981 & 0.985 & 0.043
\end{tabular}

$\mathrm{CMIN}$, minimum value of the discrepancy; $d f$, degrees of freedom; $p$, $p$-value; NFI, normed fit index; IFI, incremental fit index; TLI, Tucker-Lewis co-efficient; CFI, comparative fit index RMSEA, root mean square error of approximation.

\section{Discussion}

The contribution of this study is twofold: theoretical and practical. In terms of theoretical contribution, the results indicate that the items used to measure the satisfaction variable, its precursors and its postcedents are reliable and valid. The proposed model has thus been validated, endorsing the connections between customer satisfaction, its antecedents and its postcedents in business-to-business relationships within an emerging market context.

From a managerial perspective, the study makes a contribution by assisting the top 500 companies in South Africa to understand how trust and commitment can nurture satisfaction, which can eventually reduce opportunism and conflict. However, this result will be influenced by whether the purchasing or procurement managers observe both trust and commitment as positive. Izogo (2016, p. 378), Segarra-Moliner et al. (2013, p. 200) and Nyaga et al. (2010, pp. 102-103) confirm that in business-to-business relationships, trust, commitment and satisfaction are key foundations in securing positive exchange relationships between a buyer and supplier. However, parties to a relationship should use bilateral mechanisms that apply incentives for mutual exchange to secure a long-term relationship commitment that will reduce opportunism and conflict in the relationship building process. Therefore, it becomes important for both suppliers and buyers to remain trustworthy in terms of their business processes. This can be achieved by ensuring that both parties to the buyer-seller relationship are fair and innovative in their negotiations, that neither of them profits at the expense of the other and that both are reliable in terms of promises made during the business transactional engagement process. Furthermore, both the buyer and the supplier should ensure that they are committed to doing business with each other, that there is a long-term orientation towards the building and establishment of a relationship between them and that they both have a strong intent to do business with each other in future.

From a theoretical perspective, the study makes two contributions. Firstly, it determines that customer satisfaction within a business-to-business environment in an emerging economy secures a negative relationship with opportunism and conflict. The argument can thus be made that the more satisfied a buyer or seller is in a relationship, the less inclined they will be to display opportunistic characteristics, and the lower the possibility of conflict will be in the buyer-supplier relationship chain. Furthermore, the higher the level of opportunism in a buyer-supplier relationship, the greater the

TABLE 5: Tests of hypotheses.

\begin{tabular}{lllccl}
\hline Hypothesis & $\begin{array}{l}\text { Exogenous } \\
\text { construct }\end{array}$ & $\begin{array}{l}\text { Endogenous } \\
\text { construct }\end{array}$ & $\begin{array}{c}\text { Regression } \\
\text { weight }\end{array}$ & Significance & Finding \\
\hline 1 & Trust & Satisfaction & 0.857 & $*$ & Supported \\
2 & Commitment & Satisfaction & 0.639 & 0.013 & Supported \\
3 & Trust & Commitment & 0.272 & $*$ & Supported \\
4 & Satisfaction & Opportunism & -0.439 & $*$ & Supported \\
5 & Satisfaction & Conflict & -0.250 & $*$ & Supported \\
6 & Opportunism & Conflict & 0.419 & $*$ & Supported \\
\hline
\end{tabular}


potential for conflict in the relationship. It is also argued that the higher the level of trust in the relationship between a buyer and a seller in a business-to-business environment, the greater the commitment of both parties to the relationship, and the higher the level of satisfaction experienced. It should be noted that business-to-business relationships amongst the top 500 companies in South Africa have not been well researched before, especially with regard to the connections between satisfaction, opportunism and conflict. The findings from this study clearly illustrate what constitutes satisfaction and how it influences opportunism and conflict. The two dimensions of satisfaction could in future be applied in business-to-business research to explore the influence of satisfaction on customer retention or customer loyalty. The study makes a contribution to business-to-business theory by recommending relevant measurement dimensions.

Secondly, the study secures a better understanding of the influence of satisfaction variables on opportunism and conflict from the perspective of an emerging economy in a business-to-business environment. The study suggests a model that clarifies how trust and commitment directly influence satisfaction, with the latter influencing opportunism and conflict.

\section{Managerial and theoretical implications}

The South African business environment has become increasingly competitive since the dawn of democracy in 1994. This necessitates that managers have a clear understanding of strategies that could increase the success of their business. One approach to this is to clearly understand the relevant constructs when establishing and managing relationships in a businessto-business environment. The results of this study clearly indicate that relationship marketing and transaction cost constructs are equally important in the growth and management of sound business relationships between organisational suppliers and buyers. Parties engaging in business-to-business relationships in an emerging economy should take cognisance of the interconnectedness of trust, commitment, satisfaction, opportunism and conflict. They should understand that satisfaction can lower the chance of their organisation becoming a casualty of opportunistic behaviour by a business partner. Increasing the satisfaction experience of a business partner can also significantly reduce the chances of conflict in the business channel, leading ultimately to stronger long-term relationships. San-Martín and Jiménez (2017, p. 2212) concur, stating that enhanced levels of satisfaction in mutually beneficial relationships lower the possibility that one partner will take advantage of another and behave in an opportunistic manner. Ozkan-Tektas and Basgoze (2017, p. 389) conclude that reduced levels of conflict between parties to a relationship can be secured through increased levels of satisfaction founded on mutual benefit in the relationship building process.

Secondly, business success can be improved through the creation of closer working relationships between partners in a business-to-business environment. Securing satisfaction based on trust between parties in the value chain becomes increasingly important to lessen opportunities for opportunism. This argument is supported by Dahlstrom et al. (2014, pp. 270-271) and Chiou and Shen (2006, p. 12), who state that trust is a critical factor in the management of opportunistic behaviour and that increased levels of trust between parties can reduce opportunistic behaviour. The business managers of corporate South Africa therefore need to establish and manage a relational approach towards business partners that will enhance overall value for their respective organisations. Trust and commitment are critical in business-to-business relationships to secure increased satisfaction experiences amongst business partners. This can be established by securing fair dealings in business negotiations, refraining from business dealings aimed at unilateral profit increases at the cost of ethical business practices, delivering on promises made during business negotiations and establishing a business reputation of trustworthiness and integrity. The results of the study confirm that trust is a prerequisite for a business partner to become committed to the relationship. Committed partners have a strong willingness to do business with a supplier well into the future, which is expected to influence levels of satisfaction in future business relationships. This argument is supported by Martins, de Fariab and Campi (2017, p. 49), Wu (2013, p. 168) and Akman and Yörür (2012, p. 218), who emphasise the importance of trust in securing satisfaction in the relationship building process. They further argue that commitment is a critical factor influencing satisfaction in the relationship building process and it is founded on trust. However, should a buyer or seller in a business-to-business relationship become dissatisfied, the relationship would end, with no opportunity for future continuance. In addition, the partners in a business-to-business relationship should create relationship plans founded on the principles of inclusivity and collaboration. An approach of open engagement between the parties to a business-to-business relationship must become the foundation for the creation and maintenance of the relationship building process.

\section{Conclusions, research limitations and future research}

This study explored the interrelationships of selected constructs of a business-to-business relationship in an emerging African market. The final model illustrates that trust and commitment can be seen as positive antecedents of satisfaction, with trust being a precursor to commitment. Furthermore, satisfaction reflects a negative relationship with opportunism and conflict. The results show a good fit between the proposed constructs in the study and the business-to-business model. The results also indicate satisfactory reliability and validity for the proposed model and justify acceptance of the different hypotheses formulated for the study. A limitation of the study is the use of convenience sampling for the gathering of data. This implies that the results cannot be generalised to all large companies in South Africa or other emerging economies in 
the world. The second limitation is that the study focused only on business-to-business relationships between large companies and their suppliers in a South African context. Furthermore, the selected constructs (trust, commitment, satisfaction, opportunism and conflict) were also studied from the perspective of the buyer only. This could imply that large companies and their suppliers have a different view of trust, commitment and satisfaction and of how this could influence opportunism and conflict within a relationship building context.

Opportunities for further research include the expansion of the study to different emerging markets of the world. In addition, a more comprehensive range of supplier and buyer categories (such as medium- and small-sized companies and their suppliers) could be included in the study. Finally, different models that propose alternative precursors to satisfaction could be investigated within a businessto-business environment, and different postcedents of satisfaction could be investigated in a different business context. This kind of research could expand the research focus in the relationship marketing domain from an emerging market perspective and could illuminate how relationship quality constructs can be positioned to enhance relationship building outcomes.

\section{Acknowledgements Competing interests}

The authors declare that they have no financial or personal relationships that may have inappropriately influenced them in writing this article.

\section{Authors' contribution}

M.R.-L. was responsible for the conceptualisation of the problem, the development of the theoretical argument and the formulation of managerial implications. G.S. was responsible for the data analysis and M.M. was responsible for the write-up of the results.

\section{References}

Adamson, I., Chan, K. -M., \& Handford, D. (2003). Relationship marketing: Customer commitment and trust as a strategy for the smaller Hong Kong corporate banking sector. International Journal of Bank Marketing, 21(6/7), 347-358. https://doi. org/10.1108/02652320310498492

Akman, G., \& Yörür, B. (2012). Effects of business to business relations on customer satisfaction and loyalty in the context of a developing country. American Journal of Industrial and Business Management, 2(4), 217-229. https://doi.org/10.4236/ ajibm.2012.24028

Alhabash, S., Jiang, M., Brooks, B., Rifon, N. J., LaRose, R., \& Cotten, S. R. (2015) Online banking for the ages: Generational differences. In L. Robinson, S. R. Cotten J. Schulz, T. M. Hale \& A. Williams (Eds.), Communication and information technologies annual, Emerald Group, Bingley.

Altinay, L., Brookes, M., Madanoglu, M., \& Aktas, G. (2014). Franchisees' trust in and satisfaction with franchise partnerships. Journal of Business Research, 67(5), 722-728. https://doi.org/10.1016/j.jbusres.2013.11.034

Amin, M., Rezaei, S., \& Abolghasemi, M. (2014). User satisfaction with mobile websites: The impact of perceived usefulness (PU), perceived ease of use (PEOU) and trust. Nankai Business Review International, 5(3), 258-274. https://doi. org/10.1108/NBRI-01-2014-0005

Andaleeb, S. (1996). An experimental investigation of satisfaction and commitment in marketing channels: The role of trust and dependence. Journal of Retailing, 72(1), 77-93. https://doi.org/10.1016/S0022-4359(96)90006-8
Anderson, E., \& Weitz, B. (1992). The use of pledges to build and sustain commitment in distribution channels. Journal of Marketing Research, 29(1), 18-34. https://doi. org/10.2307/3172490

Bowden-Everson, J. L. -H., Dagger, T. S., \& Elliot, G. (2013). Engaging customers for loyalty in the restaurant industry: The role of satisfaction, trust, and delight. Journal of Foodservice Business Research, 16, 52-75. https://doi.org/10.1080/15 378020.2013.761025

Brown, J. R., Lusch, R. F., \& Smith, L. P. (1991). Conflict and satisfaction in an industrial channel of distribution. International Journal of Physical Distribution \& Logistics Management, 21(6), 15-26. https://doi.org/10.1108/EUM0000000000390

Brown, J. R., Lusch, R. F., \& Nicholson, C. Y. (1983). Conflict and power-dependence relations in retailer-supplier channels. Journal of Retailing (Winter), 59, 53-79.

Caceres, R. C., \& Paparoidamis, N. G. (2007). Service quality, relationship satisfaction, trust, commitment and business to business loyalty. European Journal of Marketing, 41(7/8), 836-867. https://doi.org/10.1108/03090560710752429

Campbell, D. (1955). The informant in quantitative research. American Journal of Sociology, 60(3), 339-342. https://doi.org/10.1086/221565

Candan, B., \& Yıldırım, S. (2008). Investigating the relationship between consumption values and personal values of green product buyers. International Journal of Economics and Management Sciences, 2(12), 29-40.

Chai, J. C. Y., \& Dibb, S. (2014). How consumer acculturation influences interpersonal trust. Journal of Marketing Management, 30(1-2), 60-89. https://doi.org/10.108 0/0267257X.2013.803140

Chang, H. H., Tsai, Y. -C., Chen, S. -H., Huang, G. -H., \& Tseng, H. (2015). Building longterm partnerships by certificate implementation: A social exchange theory perspective. Journal of Business \& Industrial Marketing, 30(7), 867-879. https:// doi.org/10.1108/JBIM-08-2013-0190

Chen, C-.F., \& Myagmarsuren, O. (2011). Brand equity, relationship quality, relationship value, and customer loyalty: Evidence from the telecommunications services. Total Quality Management \& Business Excellence, 22(9), 957-974. https://doi.org $/ 10.1080 / 14783363.2011 .593872$

Chen, P. -Y., Chen, K. -Y., \& Wu, L. -Y. (2017). The impact of trust and commitment on value creation in asymmetric buyer-seller relationships: The mediation effect of specific asset investments. Journal of Business \& Industrial Marketing, 32(3), 457-471. https://doi.org/10.1108/JSTP-11-2014-0252

Chen, Y. S., \& Chang, C. H. (2013). Towards green trust: The influences of green perceived quality, green perceived risk, and green satisfaction. Management Decision, 51(1), 63-82. https://doi.org/10.1108/00251741311291319

Cheng, J. C., Chen, C. Y., Yen, C. H., \& Teng, H. Y. (2017). Building customer satisfaction with tour leaders: The roles of customer trust, justice perception, and cooperation in group package tours. Asia Pacific Journal of Tourism Research, 22(4), 395-407. https://doi.org/10.1080/10941665.2016.1271816

Chiou, J. S., \& Shen, C. C. (2006). The effects of satisfaction, opportunism, and asset specificity on consumers' loyalty intention toward internet portal sites. International Journal of Service Industry Management, 17(1), 7-22. https://doi. org/10.1108/09564230610651552

Chiu, W., Kwag, M. S., \& Bae, J. S. (2015). Customers as partial employees: The influences of satisfaction and commitment on customer citizenship behavior in fitness centers. Journal of Physical Education and Sport, 15(4), 627-633.

Churchill, G. A. Jr. (1979). A paradigm for developing better measures of marketing constructs. Journal of Marketing Research, 16, 64-73. https://doi.org/10.1177/ 002224377901600110

Coughlan, A. T., Anderson, E., Stern, L. W., \& El-Ansary, A. I. (2001). Marketing channels (6th edn.). Prentice Hall, New Jersey.

Dagger, T. S., \& O'Brien, T. K. (2010). Does experience matter?: Differences in relationship benefits, satisfaction, trust, commitment and loyalty for novice and experienced service users. European Journal of Marketing, 44(9/10), 1528-1552. https://doi.org/10.1108/03090561011062952

Dahlstrom, R., \& Nygaard, A. (1999). An empirical investigation of ex post transaction costs in franchised distribution channels. Journal of Marketing Research, 36(2), 160-170. https://doi.org/10.2307/3152090

Dahlstrom, R., Nygaard, A., Kimasheva, M., \& Ulvnes, A. (2014). How to recover trust in the banking industry? A game theory approach to empirical analyses of bank in the banking industry? A game theory approach to empirical analyses of bank 32(4), 268-278. https://doi.org/10.1108/IJBM-03-2014-0042

Dwivedi, A., \& Johnson, L. W. (2013). Trust-commitment as a mediator of the celebrity endorser-brand equity relationship in a service context. Australasian Marketing Journal, 21(1), 36-42. https://doi.org/10.1016/j.ausmj.2012.10.001

Elsharnouby, T., \& Parsons, E. (2013). When relationship marketing goes wrong: Opportunism and consumer well-being in consumer-bank relationships. Journal of Relationship Marketing, 12(2), 141-163. https://doi.org/10.1080/15332667.20 13.794103

Ercis, A., Unal, S., Candan, F. B., \& Yildirim, H. (2012). The effect of brand satisfaction trust and brand commitment on loyalty and repurchase intentions. In Social and Behavioral Sciences. Papers read at the 8th International Strategic Management Conference, 2012, (pp. 1395-1404).

Farrelly, F. J., \& Quester, P. G. (2005). Examining important relationship quality constructs of the focal sponsorship exchange. Industrial Marketing Management, 34(3), 211-219. https://doi.org/10.1016/j.indmarman.2004.09.003

Fatima, J. K., Razzaque, M. A., \& Mascio, R. D. (2015). Modelling roles of commitment on rapport and satisfaction. International Journal of Bank Marketing, 33(3), 261-275. https://doi.org/10.1108/IJBM-11-2013-0130

Ferna'ndez-Sabiote, E., \& Roma, S. (2016). The multichannel customer's service experience: Building satisfaction and trust. Service Business, 10, 423-445. https:// doi.org/10.1007/s11628-015-0276-z 
Fullerton, G. (2011). Creating advocates: The roles of satisfaction, trust and commitment. Journal of Retailing and Consumer Services, 18(1), 92-100. https:// doi.org/10.1016/j.jretconser.2010.10.003

Gülşen, A., \& Bahadır Y. (2012). Effects of business to business relations on customer satisfaction and loyalty in the context of a developing country. American Journa of Industrial and Business Management, 2, 217-229. https://doi.org/10.4236/ ajibm.2012.24028

Garbarino, E., \& Johnson, M. S. (1999). The different roles of satisfaction, trust, and commitment in customer relationships. Journal of Marketing, 63(2), 70-87. https://doi.org/10.1177/002224299906300205

Geyskens, I., Steenkamp, J. E. M., \& Kumar, N. (1999). A meta-analysis of satisfaction in marketing channel relationships. Journal of Marketing Research, 26, 223-238. https://doi.org/10.2307/3152095

Gummesson, E. (2002). Relationship marketing in the new economy. Journal of Relationship Marketing, 1(1), 37-57. https://doi.org/10.1300/J366v01n01_04

Gummesson, E. (2017). From relationship marketing to total relationship marketing and beyond. Journal of Services Marketing, 31(1), 16-19. https://doi.org/10.1108/ JSM-11-2016-0398

Hair, J. F., Black, W. C., Babin, B. J., Anderson, R. E., \& Tatham, R. L. (2006). Multivariate data analysis (6th edn.). Upper Saddle River, NJ: Prentice-Hall.

Han, H., \& Hyun, S. S. (2015). Customer retention in the medical tourism industry: Impact of quality, satisfaction, trust, and price reasonableness. Tourism Management, 46, 20-29. https://doi.org/10.1016/j.tourman.2014.06.003

Hess, J., Story, J., \& Danes, J. (2011). A three-stage model of consumer relationship investment. Journal of Product \& Brand Management, 20(1), 14-26. https://doi. investment. Journal of Product \& B
org/10.1108/10610421111107987

Hong, I. B., \& Cho, H. (2011). The impact of consumer trust on attitudinal loyalty and purchase intentions in $\mathrm{B} 2 \mathrm{C}$ e-marketplaces: Intermediary trust vs. seller trust. International Journal of Information Management, 31(5), 469-479. https://doi. org/10.1016/j.ijinfomgt.2011.02.001

Hutchinson, D., Singh, J., Svensson, G., \& Mysen, T. (2011). Antecedents and postcedents of satisfaction in business relationships in Canada. International Journal of Logistics Economics and Globalisation, 3(4), 189-209. https://doi. org/10.1504/IJLEG.2011.044960

Izogo, E. E. (2016). Structural equation test of relationship quality repurchase intention - willingness to recommend framework in retail banking. International Journal of Emerging Markets, 11(3), 374-394. https://doi.org/10.1108/IJOEM-07-2015-0130

Jiang, Z., Henneberg, S. C., \& Naudé, P. (2011). Supplier relationship management in the construction industry: The effects of trust and dependence. Journal of Business \& Industrial Marketing, 27(1), 3-15. https://doi.org/10.1108/08858621211188920

Jöreskog, K. G., \& Sörbom, D. (1976). LISREL III: Estimation of linear structural equations systems by maximum likelihood methods. Chicago, IL: National equations systems by
Educational Resources.

Karnani, A. (2008). Essence of strategy: Controversial choices. in P. Kumar \& P. Ramsey (Eds.). Learning and performance matter (pp. 28-34). London: World Scientific. https://doi.org/10.1142/9789812771933_0007

Kasuma, J., Ung, T. S., Kanyan, A., Kamri, T., \& Yacob, Y. (2016). Determinants of micro enterprise owners' loyalty towards their favourite banks. Procedia - Social and Behavioral Sciences, 224, 301-307. https://doi.org/10.1016/j.sbspro.2016.05.489

Kaur, H., \& Soch, H. (2013). Mediating roles of commitment and corporate image in the formation of customer loyalty. Journal of Indian Business Research, 5(1), 33-51. https://doi.org/10.1108/17554191311303376

Kim, G. -J. (2014). Applying service profit chain model to the Korean restaurant industry. International Journal of Hospitality Management, 36, 1-13. https://doi. industry. International Journal of
org/10.1016/j.ijhm.2013.07.008

Kruger, L. -M., Mostert, P., \& de Beer, L. T. (2015). Relationship intention and satisfaction following service recovery: The mediating role of perceptions of service recovery in the cell phone industry. SAJEMS, 18(4), 608-628. https://doi. org/10.4102/sajems.v18i4.1387

Lee, D., Moon, J., Kim, Y. J., \& Yi, M. Y. (2015). Antecedents and consequences of mobile phone usability: Linking simplicity and interactivity to satisfaction, trust,
and brand loyalty. Information \& Management, 52, 295-304. https://doi. org/10.1016/j.im.2014.12.001

Lee, D. Y. (2001). Power, conflict, and satisfaction in IJV supplier - Chinese distributor channels. Journal of Business Research, 52, 149-160. https://doi.org/10.1016/ S0148-2963(99)00067-3

Li, Y., Li, G., \& Feng, T. (2015). Effects of suppliers' trust and commitment on customer involvement. Industrial Management \& Data Systems, 115(6), 1041-1066. https://doi.org/10.1108/IMDS-11-2014-0351

Liao, K. H. (2016). Impact of traditional Chinese culture on business-to-business relationship marketing and service firm performance., Journal of Business-to-Business relationship marketing and service firm performance., Journal of Business-to-Busine
Marketing, 23(4), 277-291. https://doi.org/10.1080/1051712X.2016.1250594

Lindgreen, A., Hingley, M. K., Grant, D. B., \& Morgan, R. E. (2012). Value in business and industrial marketing: Past, present, and future. Industrial Marketing Management, 41, 207-214. https://doi.org/10.1016/j.indmarman.2011.11.025

Martins, D. M., de Fariab, A. C., \& Campi, L. (2017). The level of influence of trust, commitment, cooperation, and power in the interorganizational relationships of Brazilian credit cooperatives. Revista de Administração, 52, 47-58. https://doi. org/10.1016/j.rausp.2016.09.003

Mazaheri, E., Basil, D. Z., Yanamandram, V., \& Daroczi, Z. (2011). The impact of pre existing attitude and conflict management style on customer satisfaction with service recovery. Journal of Retailing and Consumer Services, 18(3), 235-245. https://doi.org/10.1016/j.jretconser.2010.11.004

Mclvor, R. (2009). How the transaction cost and resource-based theories of the firm inform outsourcing evaluation. Journal of Operations Management, 27(1), 45-63. https://doi.org/10.1016/j.jom.2008.03.004
Meghwani, S. S., \& Thakur, M. (2017). Multi-objective heuristic algorithms for practical portfolio optimization and rebalancing with transaction cost. Applied Soft Computing, September. Retrieved from https://doi.org/10.1016/j.asoc.2017. Soft Comp
09.025

Melewar, T. C., Foroudi, P., Gupta, S., Kitchen, P. J., \& Foroudi, M. M. (2017). Integrating identity, strategy and communications for trust, loyalty and commitment. European Journal of Marketing, 51(3), 572-604. https://doi.org/10.1108/EJM-082015-0616

Morgan, R. M., \& Hunt, S. D. (1994). The commitment-trust theory of relationship marketing. Journal of Marketing, 58(3), 20-38. https://doi.org/10.1177/0022242 99405800302

Mpinganjira, M., Bogaards, M., Svensson, G., \& Mysen, T. (2014). Precursors and outcomes of satisfaction in business relationships: A replication study. Management Dynamics: Journal of the Southern African Institute for Management Scientists, 23(2), 2-13.

Mysen, T., Svensson, G., \& Lee, T. -R. (2011). Trust and commitment-based satisfaction and the impact on specific investments, formalisation and opportunism. International Journal of Business Excellence, 4(6), 696-714. https://doi.org/ 10.1504/IJBEX.2011.042906

Ndubisi, N. O. (2007). Relationship marketing and customer loyalty. Marketing Intelligence \& Planning, 25(1), 98-106. https://doi.org/10.1108/02634500710722425

Ndubisi, N. O., Malhotra, N. K., \& Wah, C. K. (2009). Relationship marketing, customer satisfaction and loyalty: A theoretical and empirical analysis from an Asian perspective. Journal of International Consumer Marketing, 21, 5-16.

$\mathrm{Ng}$, E. (2012). An empirical study on the success factors of supplier-distributor relationships. Contemporary Management Research, 8(2), 161-180. https://doi. org/10.7903/cmr.11050

Ng, E., Fang, W. T., \& Lien, C. Y. (2016). An empirical investigation of the impact of commitment and trust on internal marketing. Journal of Relationship Marketing 15(1-2), 35-53. https://doi.org/10.1080/15332667.2016.1158046

Nguyen Hau, L., \& Viet Ngo, L. (2012). Relationship marketing in Vietnam: An empirical study. Asia Pacific Journal of Marketing and Logistics, 24(2), 222-235. https://doi. org/10.1108/13555851211218039

Nyaga, G. N., Whipple, J. M., \& Lynch, D. F. (2010). Examining supply chain relationships: Do buyer and supplier perspectives on collaborative relationships differ? Journal of Operations Management, 28, 101-114. https://doi.org/ 10.1016/j.jom.2009.07.005

Ou, W. M., Shih, C. M., \& Chen, C. Y. (2015). Effects of ethical sales behaviour on satisfaction, trust, commitment, retention and words-of-mouth. International satisfaction, trust, commitment, retention and words-of-mouth. International
Journal of Commerce and Management, 25(4), 673-686. https://doi.org/10.1108/ IJCoMA-04-2013-0040

Ozkan-Tektas, O., \& Basgoze, P. (2017). Pre-recovery emotions and satisfaction: A moderated mediation model of service recovery and reputation in the banking sector. European Management Journal, 35, 388-395. https://doi.org/10.1016/j. sector. European
emj.2016.06.010

Palmatier, R. W., Dant, R. P., Grewal, D., \& Evans, K. R. (2006). Factors influencing the effectiveness of relationship marketing: A meta-analysis. Journal of Marketing, 70 136-153. https://doi.org/10.1509/jmkg.70.4.136

Parida, V., Wincent, J., \& Oghazi, P. (2016). Transaction costs theory and coordinated safeguards investment in R\&D offshoring. Journal of Business Research, 69(5), 1823-1828. https://doi.org/10.1016/j.jbusres.2015.10.063

Paswan, A. K., Hirunyawipada, T., \& Iyer, P. (2017). Opportunism, governance structure and relational norms: An interactive perspective. Journal of Business Research, 77, 131-139. https://doi.org/10.1016/j.jbusres.2017.04.012

Payan, J. M., Hair, J., Svensson, G., Andersson, S., \& Awuah, G. (2016). The precursor role of cooperation, coordination, and relationship assets in a relationship model. Journal of Business-to-Business Marketing, 23(1), 63-79. https://doi.org/10.1080 /1051712X.2016.1148455

Peter, J. P. (1979). Reliability: A review of psychometric basics and recent marketing practices. Journal of Marketing Research, 16, 6-17. https://doi.org/10.1177/ 002224377901600102

Ping, Jr., R. A. (1993). The effects of satisfaction and structural constraints on retailer exiting, voice, loyalty, opportunism, and neglect. Journal of Retailing, 69(3), exiting, voice, loyalty, opportunism, and neglect. Journ
320-352. https://doi.org/10.1016/0022-4359(93)90010-G

Ren, G., \& Gray, B. (2009). Repairing relationship conflict: How violation types and culture influence the effectiveness of restoration rituals. Academy of Management Review, 34(1), 105-126. https://doi.org/10.5465/amr.2009. 35713307

Richard, J. E., \& Zhang, A. (2012). Corporate image, loyalty, and commitment in the consumer travel industry. Journal of Marketing Management, 28(5-6), 568-593. https://doi.org/10.1080/0267257X.2010.549195

Rindell, A., Mysen, T., Svensson, G., \& Billström, A. (2013). A validation of inputs and outputs of satisfaction in business-to-business relationships through a Nordic comparison. International Journal of Procurement Management, 6(4), 424-443. https://doi.org/10.1504/IJPM.2013.054752

Sahin, A., Kitapci, H., \& Zehir, C. (2013). Creating commitment, trust and satisfaction for a brand: What is the role of switching costs in mobile phone market? in Socia and Behavioral Sciences. Papers read at the 9th International Strategic Management Conference, 2013, (pp. 496-502).

Sahin, A., Zehir, C., \& Kitapçı, H. (2011). The effects of brand experiences, trust and satisfaction on building brand loyalty: An empirical research on global brands. Procedia - Social and Behavioral Sciences, 24, 1288-1301. https://doi. org/10.1016/j.sbspro.2011.09.143

Samiee, S., Chabowski, B. R., \& Hult, G. T. M. (2015). International relationship marketing: Intellectual foundations and avenues for further research. Journal of International Marketing, 23(4), 1-21. https://doi.org/10.1509/jim.15.0027 
San-Martín, S., \& Jiménez, N. (2017). Curbing electronic shopper perceived opportunism and encouraging trust Industrial Management \& Data Systems, 117(10), 2210-2226. https://doi.org/10.1108/IMDS-08-2016-0315

San-Martín, S., Jiménez, N. H., \& López-Catalán, B. (2016). The firms benefits of mobile CRM from the relationship marketing approach and the TOE model. Spanish Journal of Marketing, 20(1), 18-29. https://doi.org/10.1016/j reimke. 2015.07.001

Sarmento, M., Farhangmehr, M., \& Simões, C. (2015). A relationship marketing perspective to trade fairs: Insights from participants. Journal of Business \& Industria Marketing, 30(5), 584-593. https://doi.org/10.1108/JBIM-01-2013-0024

Segarra-Moliner, J. -R., Moliner-Tena, M. -A., \& Sánchez-Garcia, J. (2013). Relationship quality in business to business: A cross-cultural perspective from universities. Marketing Intelligence \& Planning, 31(3), 196-215. https://doi.org/10.1108/ 02634501311324573

Sharifi, S. S., \& Esfidani, M. R. (2014). The impacts of relationship marketing on cognitive dissonance, satisfaction, and loyalty: The mediating role of trust and cognitive dissonance. International Journal of Retail \& Distribution Management 42(6), 553-575. https://doi.org/10.1108/IJRDM-05-2013-0109

Sinnewe, E., Charles, M. B., \& Keast, R. (2016). Australia's cooperative research centre program: A transaction cost theory perspective. Research Policy, 45(1), 195-204. program: A transaction cost theory perspective
https://doi.org/10.1016/j.respol.2015.09.005

Skarmeas, D., Katsikeas, C. S., Spyropoulou, S., \& Salehi-Sangari, E. (2008). Market and supplier characteristics driving distributor relationship quality in international marketing channels of industrial products. Industrial Marketing Management, 37, 23-36. https://doi.org/10.1016/j.indmarman.2007.04.004

Standifer, R. L., Raes, A. M., Peus, C., Passos, A. M., Santos, C. M., \& Weisweiler, S. (2015) Time in teams: Cognitions, conflict and team satisfaction. Journal of Managerial Psychology, 30(6), 692-708. https://doi.org/10.1108/JMP-09-2012-0278

Su, L., Swanson, S. R., Chinchanachokchai, S., Hsu, M. K., \& Chen, X. (2016). Reputation and intentions: The role of satisfaction, identification, and commitment. Journal of Business Research, 69(9), 3261-3269. https://doi.org/10.1016/j.jbusres.2016.02.023

Sumaedi, S., Juniarti, R. P., Mahatma, I. G., \& Bakti, Y. (2015). Understanding trust \& commitment of individual saving customers in Islamic banking: The role of ego involvement. Journal of Islamic Marketing, 6(3), 406-428. https://doi.org/10.1108/ JIMA-06-2013-0045

Taylor, S. A., Donovan, L. A. N., \& Ishida, C. (2014). Consumer trust and satisfaction in the formation of consumer loyalty intentions in transactional exchange: The case of a mass discount retailer. Journal of Relationship Marketing, 13(2), 125-154. https://doi.org/10.1080/15332667.2014.910076

Theron, E., Terblanche, N. S., \& Boshoff, C. (2008). The antecedents of relationship commitment in the management of relationships in business-to-business (B2B) financial services. Journal of Marketing Management, 24(9-10), 997-1010. https://doi.org/10.1362/026725708X382019

Tsao, W. C., \& Hsieh, M. T. (2012). Exploring how relationship quality influences positive eWOM: The importance of customer commitment. Total Quality Management \& Business Excellence, 23(7-8), 821-835. https://doi.org/10.1080/ 14783363.2012.661137
Valenzuela, F. (2005). Trust and commitment as mediating variables in the relationship between satisfaction and hotel guest loyalty. (Papers read at the annual ANZMAC conference held in Australia - New Zealand. 2005. pp. 87-93.)

Varela-Neira, C., Vázquez-Casielles, R., \& Iglesias, V. (2010). Explaining customer satisfaction with complaint handling. International Journal of Bank Marketing 28(2), 88-112. https://doi.org/10.1108/02652321011018305

Veloutsou, C. (2015). Brand evaluation, satisfaction and trust as predictors of brand oyalty: The mediator-moderator effect of brand relationships. Journal of Consumer Marketing, 32(6), 405-421. https://doi.org/10.1108/JCM-02-2014-0878

Verma, V., Sharma, D., \& Sheth, J. (2016). Does relationship marketing matter in online retailing? A meta-analytic approach. Journal of the Academy of Marketing Science, 44(2), 206-217. https://doi.org/10.1007/s11747-015-0429-6

Vieira, V. A., Monteiro, P. R. R., \& Veiga, R. T. (2011). Relationship marketing in supply chain: An empirical analysis in the Brazilian service sector. Journal of Business \& Industria Marketing, 26(7), 524-531. https://doi.org/10.1108/08858621111162325

Vincent, N. A., \& Webster, C. M. (2013). Exploring relationship marketing in membership associations. European Journal of Marketing, 47(10), 1622-1640. https://doi.org/10.1108/EJM-06-2011-0296

Voldnes, G., Grønhaug, K., \& Nilssen, F. (2012). Satisfaction in buyer-seller relationships-Influence of cultural differences. Industrial Marketing Management, 41, 1081-1093. https://doi.org/10.1016/j.indmarman.2012.03.001

Wang, C. L., Shi, Y., \& Barnes, B. R. (2015). The role of satisfaction, trust and contractual obligation on long-term orientation. Journal of Business Research, 68, 473-479. https://doi.org/10.1016/j.jbusres.2014.09.016

Wang, S. W., Ngamsiriudom, W., \& Hsieh, C. H. (2015). Trust disposition, trust antecedents, trust, and behavioral intention. Service Industries Journal, 35(10), 555-572.

Wu, H. C., Cheng, C. C., \& Ai, C. H. (2018). A study of experiential quality, experiential value, trust, corporate reputation, experiential satisfaction and behavioral intentions for cruise tourists: The case of Hong Kong. Tourism Management 66, 200-220. https://doi.org/10.1016/j.tourman.2017.12.011

Wu, I. -L. (2013). The antecedents of customer satisfaction and its link to complaint intentions in online shopping: An integration of justice, technology, and trust. International Journal of Information Management, 33, 166-176. https://doi. org/10.1016/j.ijinfomgt.2012.09.001

Yasuda, H. (2005). Formation of strategic alliances in high-technology industries: Comparative study of the resource-based theory and the transaction-cost theory. Technovation, 25(7), 763-770. https://doi.org/10.1016/j.technovation.2004.01.008

Zabkar, V., \& Brencic, M. M. (2004). Values, trust, and commitment in business to business relationships: A comparison of two former Yugoslav markets. International Marketing Review, 21(2), 202-215. https://doi.org/10.1108/02651330410531402

Zaheer, A., McEvily, B., \& Perrone, V. (1998). Does trust matter? Exploring the effects of interorganizational and interpersonal trust on performance. Organization Science, 9(2), 141-159. https://doi.org/10.1287/orsc.9.2.141

Zhou, Y., Zhang, X., Zhuang, G., \& Zhou, N. (2015). Relational norms and collaborative activities: Roles in reducing opportunism in marketing channels. Industrial Marketing Management, 46, 147-159. https://doi.org/10.1016/j.indmarman.2015.01.014 